\title{
THE POLITICS OF ELECTORAL REFORM IN NIGERIA, 2007-2011
}

\author{
Emmanuel Remi Aiyede \\ Dr Aiyede is Senior Lecturer in the Department of Political Science and \\ Coordinator of the Leadership and Governance Programme at the Centre for \\ Sustainable Development of the University of Ibadan, Nigeria \\ email: eaiyede@yahoo.com
}

The 2011 general elections in Nigeria were very interesting. According to the reports of election observers and monitors they were an improvement on any held since the country returned to democratic rule in 1999. The outcome, however, was attended by some drama.

The elections were postponed for logistical reasons after they had been running for a few hours on 9 April, raising fears that the process might be frustrated.

Violence broke out in certain states in the northern part of the country after the presidential election on 23 April when it was obvious that Muhammadu Buhari, the presidential candidate of the Congress for Progressive Change (CPC), who hails from the North, had lost to the incumbent, President Goodluck Jonathan. This forced the electoral commission to postpone the date of the subsequent gubernatorial elections in Kaduna and Bauchi states for two days, until security could be guaranteed.

Several cases were instituted in the courts to challenge the outcome of some of the elections, including the presidential election. The courts disposed of many of these within the 180-day time limit demanded by the Electoral Act 2010 (as amended). Few of the court decision were groundbreaking and none of the gubernatorial elections was overturned. The Supreme Court decided in favour of President Jonathan on 28 December.

The elections were preceded by important developments in the country since the discredited elections of 2007. On assuming office President Umaru Musa Yar'Adua, who was to die in office, admitted that the 2007 elections had been flawed, thereby confirming the conclusions reached earlier by both local and foreign monitors and observers that they were the worst in the electoral history of the country. In an unprecedented move the courts set aside several election results and, in some cases, determined the winners. 
On 26 November 2010 the Appeal Court removed the governor of Osun State, Olagunsoye Oyinlola, of the People's Democratic Party (PDP), and declared his opponent, Rauf Aregbesola of the Action Congress (AC), the winner. This was the sixth gubernatorial election determined by the courts in which the governor was replaced (the others were Rivers, Anambra, Edo, Ekiti, and Ondo states). In several other cases (Kogi, Cross Rivers, Bayelsa, Sokoto and Adamawa) the elections were annulled and fresh elections called.

Further, judicial decisions extended the terms of five governors in these states who had participated in and won the various gubernatorial elections that had to be rerun. (The governors whose tenure was extended remained in power until the Supreme Court rejected the decision of the lower court on 26 December 2011.) These decisions had some effect on the logistical challenges and on electoral malpractice and other misdemeanours that usually accompany elections in Nigeria. They effectively limited the gubernatorial elections of 2011 to 25 of the 36 states. New governors will not be elected in Ekit and Anambra states until 2014, while Edo and Ondo states will hold elections in 2012.

President Yar'Adua set up an electoral reform committee headed by Justice Mohammed Uwais on 28 August 2007 to investigate the 2007 elections and to propose reform measures to improve the electoral process in the country. After receiving memoranda from several individuals and groups, conducting public hearings around the country and commissioning studies that informed its final recommendations, the committee submitted its report on 11 December 2008.

It found that the factors responsible for electoral irregularities, malpractice, disruptions and violence 'include, among others, the character of the Nigerian state as the arena of electoral contests, the existence of weak democratic institutions and processes, negative political culture, weak legal/institutional framework, and lack of independence and capacity of electoral management bodies'.

To make the Independent National Electoral Commission (INEC) truly independent, the committee recommended the removal of the power of the president to appoint its chairperson and members and suggested that the National Judicial Council be empowered to do so. INEC was to be reorganised and to be funded directly by the country's Consolidated Revenue Fund and the independent electoral commissions of the states were to be incorporated into the structure of INEC.

The committee also recommended a mixed electoral system comprising elements of proportional representation, including the idea that parties that win 2.5\% of the seats in the National Assembly be considered for Cabinet-level appointments, to reduce the intensity of electoral competition. Several ways of making the political process more inclusive through the electoral process, including gender balance, were also proposed. The committee recommended 
the establishment of a Centre for Democratic Studies for civic and political education.

The Uwais committee called for an Electoral Offences Commission to be set up to prosecute electoral offenders and recommended that at least five judges should sit when the Court of Appeal hears appeals relating to election petitions. It also recommended that election disputes be concluded before candidates are sworn in and that the process of adjudicating election disputes be concluded within six months. It further recommended that the burden of proof in the case of election petitions should shift from the petitioner to INEC; when challenged INEC must prove that the elections were free and fair.

These recommendations involve constitutional, statutory, administrative and institutional changes. To fast track the process of implementation the committee recommended that the constitutional amendments involved in the proposed electoral reforms should not be submerged in the larger effort to review the 1999 Constitution but should be considered separately. The committee prepared three draft Bills: amendments to the 1999 Constitution, amendments to the Electoral Act 2006 and an amendment relating to the establishment of the Electoral Offences Commission. The committee was apparently convinced that the president and his party were committed to carrying out fundamental electoral reforms.

The recommendations were reviewed by both the Federal Executive Council and the National Council of States and a white paper was released by the government rejecting important aspects, among them the removal of the power of the president to appoint the chair and members of INEC and the incorporation of the state independent electoral commissions into the structures of INEC. In the white paper the government argued that the appointment of the INEC chair was an executive function, not one for the judiciary.

President Yar'Adua sent seven Bills to the National Assembly to further underscore his commitment to electoral reform. The Bills did not, however, enjoy the support of the Assembly. The Senate threw out a Bill increasing the membership and extending the tenure of members of INEC because it involved constitutional amendments. The Bill relating to the establishment of the Political Parties Registration Commission was also thrown out because, it was argued, it involves an unnecessary duplication of the functions of INEC.

As the drama over the electoral reform Bills unfolded the president became ill and politicking over his ill health took centre stage when he left for Saudi Arabia for medical attention without transferring responsibility to the vice-president by means of a written notification to the National Assembly, as prescribed by the Constitution. His absence became a major issue of concern and debate as the country drifted without presidential leadership and on 2 February 
2010 the National Assembly declared the vice-president, Goodluck Jonathan, acting president, by resorting to what it called the 'doctrine of necessity'.

After about 80 days abroad Yar'adua was secretly returned to the country in March 2010 under cover of night, without Jonathan's knowledge. On 5 May he died and his burial opened the space for meaningful engagement with the electoral process.

Thus it was that Jonathan took over responsibility for the electoral reforms Yar'adua had initiated. Jonathan, who was a candidate for the presidency in the 2011 elections, promised to deliver free and fair elections. To buttress his commitment, on 8 June 2010 he appointed Attahiru Jega, former president of the Academic Staff Union of Universities, a member of the electoral reform committee and a political scientist, to chair the electoral commission and oversee the elections.

One of the key areas of electoral reform relates to party primaries. Indeed, a major reform initiative focused on internal party democracy. This was also a key area of parliamentary activism because of the high turnover in the national Parliament, which many parliamentarians attributed to the excessive powers of governors in selecting party delegates during primaries.

Many legislators laboured to ensure that the powers of the governors were watered down by amendments to the Electoral Act. The zoning arrangement of the dominant party, the People's Democratic Party (PDP), which involved the allocation and rotation of party nominees for various political offices among the geopolitical zones and states in the country, was upset, first by Jonathan's ascent to the office of president following the death of Yar'Adua and then by the fact that he stood in the party's presidential primaries and emerged as the PDP's flag bearer and winner of the 2011 presidential elections.

The delay in appointing the new INEC chair and commissioners created fresh challenges with regard to the time frame for the elections. The Constitution and the Electoral Act of 2010 were amended to accommodate the limited time available in order to avoid an extension of the handover date beyond 29 May 2011. Other important changes made to the Constitution and the Act related to the funding of and qualification for membership of INEC, the announcement of election results at polling units, the 180-day deadline set for decisions by a tribunal on an electoral petition, a demand for party primaries to determine party nominees and provision for the continuous registration of voters.

The build-up to the elections was remarkable for its uncertainty about the outcome. This was because the PDP's dominance had been reduced by the courts' reversal of several of the 2007 results. The electorate and opposition parties were more confident about the capacity of the courts to adjudicate election cases independently, despite the protracted process relating to the 2007 elections. 
The president had consistently maintained that these elections would be different from their predecessors and that every vote would count. The fact that these were the fourth general elections in Nigeria since the return to democratic rule in 1999 and the extent to which the events that followed the 2007 elections and the institutional changes that were made, affected the outcome and the general character of the 2011 elections. It is these factors that constitute the focus of this issue.

In the first article Abubakar examines the legal and constitutional framework of the elections from the perspective of governmentality, as an element of the techniques of power and the exercise of social and political domination. He argues that the political class in Nigeria has exercised governmental power to the detriment of the citizenry. The spectre of centralisation of power through neo-patrimonial networks entrenches elite pillage, which undermines the ethos of participatory democracy and constitutionalism. Thus, he calls for a reconstitution of the institutional logic of the Nigerian state in such a manner that it will enhance the empowerment of the citizenry. He also calls for the enthronement of a transparent, inclusive, developmentalist and responsive system of governance. Specifically, he believes that a mixed electoral system will deepen inclusion in decision-making and enhance the empowerment of citizens.

Aiyede takes up the debate over power sharing in the build-up to the 2011 elections provoked by the entrance of Goodluck Jonathan (a southerner) into the presidential race, made possible by the death of President Umar Musa Yar'Adua (a northerner), which upset the power-sharing arrangement of the PDP in the context of Nigeria's federal system. He provides a rich empirical picture of the politicking over the allocation of public office by Nigerian politicians and how these played out in the PDP's presidential primaries and the presidential election. He argues that while the 'zoning with rotation' principle remains useful for stability and representation in Nigeria it depends increasingly on the moderate behaviour and creativity of the power elites as they negotiate and manage the power disequilibrium that results from perceived access or lack of access of segments of Nigerian society to top political office. However, he rejects the 'zoning with rotation' principle as a long-term solution on the grounds that it constrains the notion of free political competition and the uncertain outcomes that are central to democracy.

Omotola \& Aiyedogbon engage political participation as measured by voter turnout in the 2011 general elections, presenting a tapestry of discernible variations across geopolitical zones. Overall, turnout for the presidential election was $53.7 \%$. They argue that this could be improved upon by the use of social media, electoral reform, active engagement of civil society, a reduction in violence and the provision of incentives to voters, political education and mobilisation and other ideas contained in the Uwais report. 
Nothing demonstrates the relative disadvantage of women in Nigerian politics better than the outcome of the PDP primary, with a female presidential candidate who received only one vote. Pogoson reexamines the influence of patriarchal disposition on women's participation as equal stakeholders in democratic politics and party decision-making organs since 1999, when Nigeria returned to democratic rule. She shows that the marginalisation of women defies legal and constitutional guarantees and must be tackled simultaneously with patriarchy through continuous dialogue between women and male leaders, endorsing and entrenching a quota system/mechanism in national and political party constitutions; the review of electoral systems and adoption of those most conducive to women's participation (for example, proportional representation) and the provision by political parties of funding to enable women politicians to challenge electoral malpractices in court.

The issue of gender is deepened by Okosi-Simbine's close look at the results of the elections. She observes a slight drop in the number of women in elected positions relative to men and compared to the numbers after the 2007 elections. Attributing this to structural issues of religion and culture, women's lack of access to funds, 'godfatherism' in the political parties and the undemocratic disposition of party leaders, political and electoral violence, and vote buying, she declares that the poor participation of women in politics casts doubt on Nigeria's democratic credentials.

Nwolise reviews the security arrangements for the various phases of the elections, which underpinned the relative peace and order experienced during that period. He argues that security guarantees ensured that peace, thereby contributing to the credibility of the elections. He argues further that the neutrality of the security agencies reflects the commitment of the president to ensuring free and fair elections and therefore an uncompromised use of security agencies.

Aiyede \& Aregbeyen examine the cost of the elections, estimating the financial cost to have been about N566.2-billion, representing about $2 \%$ of the country's gross domestic product. They identify non-monetary costs as including the loss of life and property in the violence that followed the elections, arguing that the cost of the 2011 elections was too high for the sustenance of democracy. Hopeful that the cost of future elections would be lower, they identify the poor state of the infrastructure, the use of imported technology for the biometric registration exercise, the postponement of some of the elections and the staggering of the elections over several days as responsible for the huge financial outlay. They show the difficulties involved in estimating the cost of an election, among them the poor record keeping of political parties, their weak public disclosure practices and the failure to enforce laws that regulate party and campaign finance.

The final article deals with the monitoring and observation of the elections. Here, Adesina maintains that the resounding approval by monitors and observers 
of the elections as an improvement on previous ones must be qualified, given the level of irregularities and violence that characterised the elections. She argues, further, that in declaring the elections credible monitors and observers must not lose sight of their inadequacies if Nigeria is to reap the benefits of monitoring and observation.

It is hoped that this review of the experiences of the 2011 elections and their aftermath will provide ideas for electoral reforms for future elections in Nigeria and in divided societies in general. 